\title{
A Hypnotising Dance of Bodies: The Case of Stephen King
}

\author{
Folio Jessica \\ University of Reunion Island, Saint-Denis, France
}

\begin{abstract}
King's narratives exemplify the themes of the uncanny, of masking and unmasking, of the corporeal otherisation and of the questioning of identity. This paper is an invitation to go beyond what may commonly be thought of as a uniform looking-glass so as to discover King's particular treatment of the body. Far from shying away from sexuality, the American writer depicts it in an ambivalent or disguised manner (Thinner, Mr. Mercedes, Christine, Misery, Cycle of the Werewolf). If the female body is mainly connected with the taboos of rape and incest (Gerald's Game, Dolores Claiborne, Bag of Bones, Under the Dome), or with ungenderisation (The Tommynockers, Rose Madder), the notion of monstrosisation can nevertheless be applied to both male and female bodies (The Shining, Desperation, “The Raft,” "Survivor Type”). Oscillating between hypermonstration and avoidance, King pulls the strings of the fragmentation, even of the silencing of the body. The fissure impregnating the characters' identity and bodies is enlightened by the shattering of the very connection between signifiers and signified, inserting the reader into a state of non-knowledge: a mesmerising dance of disembodied bodies within disembodied texts.
\end{abstract}

Keywords: the body, in-betweeness, otherisation, sexuality, taboos, ambiguity, fragmentation, non-knowledge

\section{Introduction}

In his introduction to Night Shift, King writes: "all our fears are part of that great fear-an arm, a leg, a finger, an ear. We're afraid of the body under the sheet. It's our body” (King, 1978, p. 12). This quotation reveals an abjectified relation with the body_abject in the Kristevan sense of a mingling of attraction and repulsion — and encompasses the problematical issues laying at the core of King's work: a pondering over a unified vision of the body, a questioning of identity, but also a congruence of both a monstration and a masking of the corporeal essence. The quotation also highlights the theme of the Grim Reaper and opens the door on the shattered supposed mastery of our own body. King's texts depict the invasion of the body and the innumerable engendered consequences. The theme of invasion immediately establishes a bridge with the unveiling of the themes of sexuality and its taboos which unexpectedly permeate the mainstream American writer's narratives.

Sexuality is ambivalently draped in a redempting veil or appears in a disguised manner and, in that case, a link is established with the crushing of the female and male bodies. King addresses the taboos of incest and rape, incest being ambiguously presented as a case of fragmentation of identity and paradoxically as a quasi initiatory trial. King's emphasis on the blurring of gender, the hypnotising otherization and monstrosization of the body echo a dislocation of the text itself, conveying an impossible quest for a total knowledge of the body.

Folio Jessica, Ph.D. in American Literature, University of Reunion Island. 


\section{An Ambivalent Vision of Sexuality}

Mr. Mercedes (2014) depicts the life of retired and suicidal detective, Bill Hodges. Confining himself in his house after the unresolved case of the Mercedes killer who drove into a crowd at a job fair, thus killing eight people, Bill plays with his dad's old revolver by putting it inside his mouth. Filled with sexual innuendos, this act combines pleasure and death; it echoes the Mercedes killer's sexual arousal when killing the people at the job fair: "when I 'put the pedal to the metal' and drove poor Mrs Olivia Trelawney's Mercedes at that crowd of people, I had the biggest 'hard-on' of my life!” (King, 2014, p. 23). The text is marked by the sexual tension conveyed by this specific sexualized murdering of people: the rhythmical alternation of short and long sentences conveys the increased rhythm before the relief of the sexual tension. The car replaces the sexual organ to obtain pleasure at the moment of impact with the crowd and the killer even wears a condom.

This deviant vision of sexuality contrasts with its healing, rejuvenating aspect for the detective who meets during his personal investigation Jannelle Patterson, the Mercedes owner's sister. The sexual act is then depicted as an auxiliary of rebirth: "the clinging, slippery warmth of her encloses him in a warm hug” (King, 2014, p. 185); "with Janey Patterson nestled next to him, he sleeps ... and never so well since childhood” (King, 2014, p. 196). The regained and rediscovered pleasure instils a return to the lost paradise of the innocence of childhood. Sexuality is addressed in relation to Jannelle's body viewed as enticing and to the detective's body which triggers desire despite its obesity: "she grabs the hardness of him through his underpants and wiggles it like a gearshift, making him gasp” (King, 2014, p. 184). The sexual act brings forth the epitome of pleasure, enhances Bill's masculinity and Jannelle's overwhelming power over his desire.

In The Dead Zone (1979), the issue of the fragmented body is at stake. Following a cab accident, the hero, Johnny Smith, remains in a coma which leaves him and his girlfriend, Sarah, literally sexless: "she and Johnny had not been to bed" (King, 1979, p. 21). Johnny's body is depicted as shrinking away in his hospital bed: "he had begun to pull into a fetal shape” (King, 1979, p. 100). After he miraculously wakes up and suffers through physical therapy, Sarah and him decide to make up once for this dead zone of four and a half years in their respective lives. The text insists on physical sufferings, on Sara's discovery of his traumatised body and on her desire despite this trauma: "he kissed her between the shoulder blades and she shivered” (King, 1979, p. 239). The text echoes this fragmented perception of the body. The preliminaries are characterised by suspension points; sentences become shorter and shorter, inscribing the theme of incompleteness in the body of the text itself. “'There's something I'd like to finish,' she said simply. 'Something we never had the chance to finish” (King, 1979, p. 236).

The intercourse itself seems lost in the mentioning of the body movements or sensations:

...her hips moving in a quickening tempo. Her voice was far away. The touch of her hair was like fire on his shoulder and chest. He plunged his face deeply into it, losing himself in that dark-blonde darkness. [...] “All I want is what was taken from us”. (King, 1979, p. 237)

The sexual intercourse intents at filling up the void left by the accident. The stress is laid not only on bodily sensations_-“feel, smell, flesh, hips, touch"-but also on imageries of completeness: "sinking into her was like sinking into an old dream that had never been quite forgotten”. King renders through the mentioning of the acme of pleasure and the ternary rhythm — “at some point she cried out his name, again and again and again, like a chant” (King, 1979, p. 239)—the quest for unicity and the sense of closure. 
Thinner (1984) presents sexuality in an ambivalent manner. It is first viewed as a means of gratification for the protagonist, Billy Halleck, for winning a law case:

They had just finished making love. It was the sixth time in three days, a giddy change from their usual sedate twice-a-week pace $[\ldots]$ Her hand wandered up from his thigh, touched his penis lightly and lovingly, toyed with the thatch of his pubic hair. (King, 1984, pp. 21-22)

What is shown is the moment just after the sexual intercourse. If the words "penis" and "pubic hair" are mentioned, there is no description of the intercourse itself.

Sex is a means of celebration after the medical results indicate Billy is free from cancer or used as an auxiliary of reconciliation following the protagonist's trauma of transforming himself into a living skeleton because of a gypsy curse: "he began thinking, This one is for her, and discovered it had been for himself after all...” (King, 1984, p. 106). It helps sleep and attain oblivion of the traumatic events of the day. In both cases, there is no monstration of the act left as a mere statement.

Nevertheless, sexuality, with references to the body, is more detailed when it is in connection with death:

Here was his wife gripping his own stiffening member. And, by damn, she was beginning to jerk him off. [...] he had reached for her with his right hand and she had pulled her skirt up, exposing a perfectly ordinary pair of yellow nylon panties. Those panties had never excited him before, but they did now... or perhaps it was the way she had pulled her skirt that excited him; she had never done that before, either. (King, 1984, p. 76)

The rise in pleasure goes along with moments of acceleration and pauses in the text and the moment of orgasm correspond to the death of a gypsy woman stepping out in front of the protagonist's car:

\footnotetext{
He was on the verge of an explosive orgasm, all but the tiniest fraction of his consciousness fixed below his waist as Heidi's hand squeezed and relaxed, slipped up and down with slow and delicious friction, paused, squeezed and relaxed again. Heidi's hand had clamped on him, stifling the orgasm that shock had brought on for one endless second of pain and a pleasure that was inevitable but still gruesome. (King, 1984, p. 77)
}

The inevitable abject pleasure, the intermingling of sexuality and death constitute Billy's closeness to orgasm and are conjoined with the stepping out of the gypsy woman in front of his car. The sexual act parallels a more abhorrent lethal contact between the female body and the elongated phallic car. The tension of the act is signalled by repetitions in the text, by an alternation established between Billy's reaction and the emphasis laid on the movements of Heidi's hand that tend to liken the reaching of acme with the little death.

In those three previous examples, sex ambivalently has regenerative or lethal connotations and is combined with the monstration of precise parts of the body. The link established between sexuality and the revealing of the female or male bodies is clear in such novels as Christine (1983a), The Cycle of the Werewolf (1983c), or Misery (1987).

In Christine, King makes use of a symbol of the consumption society, a car, and turns it into a female monster. Sold to the teenage Arnie Cunnigham, the red Plymouth takes possession of Arnie's spirit and body. Feminized and monstrosized, the car is presented as a substitute for love and sex. Arnie feels desire for the car and admires its curves from the moment he lays eyes on it. His baffled desire for his girlfriend and the inaccessibility to certain parts of her body seem to be displaced on his car. The preliminaries are established by Arnie with his car under the form of caresses: "Arnie touched possessively, and the touch turned into a caress" (King, 1983a, p. 181). Arnie is out of breath and in a trance once inside the car: "Arnie and Christine were welded together in a disturbing parody of the act of love” (King, 1983a, p. 234). He forgets his backache or the 
rejection by the loved ones: "she'd never argue or complain, Arnie thought. She'd never demand. You could enter her anytime and rest on her plush upholstery, rest in her warmth" (King, 1983a, p. 381). The sexual innuendos are made clear with the use of the verb "enter" and the noun "warmth" and are underlined by the smell of the vehicle compared to the female genitalia.

The feminisation of the car, "he loved and loathed her, he hated her and cherished her, he needed her and needed to run from her” (King, 1983a, p. 381), going along with Arnie’s disguised and morbid sexual relationship brings a new light to the smashing of the car, its disassembling, the puncturing with holes and the shitting on the dashboard perpetrated by the bullies Buddy Repperton and his friends. Soiled, entirely debased, Christine is the victim of a collective rape. Repperton gives the Plymouth the eloquent name of "whore" before being run over.

Repperton's killing is equally prominently sexualized. Christine's engine is out of breath like in a sexual intercourse: "the rumble of her engine was like the slow panting of some gigantic animal" (King, 1983a, p. 346); Repperton himself is depicted as "panting hoarsely, he threw himself through the empty space where the windscreen had been. [...] Buddy licked his lips". The rise in pleasure is expressed as such: "Christine’s engine gunned and fell off; gunned and fell off. [...] Christine’s engine, revving and falling off, revving and falling off, now more quickly, more urgently” (King, 1983a, p. 346). The moment of impact marks the relief of tension:

Christine's engine screamed and she came at him, rear end flirting back and forth as her tyres spun through the sugary snow. The crimped hood was like a mouth in a frozen snarl. [...] Blood ran down his cheek from the hole in his head where his ear had been. [...] His breath came in whistling sobs. Christine paused. White vapour drifted from her exhaust; her engine throbbed and purred. (King, 1983a, p. 347)

The mentioning of the engine, the rear end, the tyres, the hood, and the exhaust pipe underpins the overwhelming presence of the car (inner and outer parts) and the crushing of the male body. At the image of the vagina dentata, the car consumes the victim alive, feeds from his blood.

Vampirized, Christine exemplifies the sexual threat intercourse poses for man, not only castration but death. The red colour, reminiscent of the maternal figure and of the menstrual blood, likens the car to a uterus maintaining its passengers under an embryonic form. Both a lover and a sexual predator, the car reveals the intrinsic link between sex and death and the objectification and negation of the body in the process.

Sex, death, and the body are also intricately connected in The Cycle of the Werewolf. The death of the first victim, Stella Randolph, is equated to a rape. On Valentine's Day, she is ready to lose her virginity. Her strong belief in love- "love" is the first word of the chapter "February"- and her romantic fantasies—- "love would be like a kiss at dawn"; "or the last kiss, the real one, at the end of the Harlequin romance stories” (King, 1983b, p. 3) - are shattered right from the beginning by the mentioning of the cold light of the full moon. Her unconditional need for love leads her to liken a werewolf to her long-awaited prince charming.

The rise in the sexual expectation marked by suspension points- "love and the scent of summer as he comes...” (King, 1983b, p. 4)—is combined with the equivalency made between her fantasy—-love would be like the rough feel of a man's cheek, that rub and scratch" - and the apparition of the werewolf outside her window: "and suddenly there is a scratching at the window" (King, 1983b, p. 4). The longing for jouissance visible with the repetition of the verb "come" obliterates the real shape of the creature making it: "a dark shape-amorphous but clearly masculine". "Her eyes have deceived her even in her dream. It is a man, that man, and he is so wickedly handsome [...] and he has come this moon-decked night and he will take her" (King, 
1983b, p. 4). Not only does sexuality emanate from the wolf with its eyes gleaming with cool lust and its hot breath but the revealing of her virgin bed added to the lexical references to opening, the shivers she feels once the wolf is positioned on top of her, announce her abandonment and accepted rape: “'lover,' she whispers, and closes her eyes [...] It falls upon her. Love is like dying [...] Love would be like coming” (King, 1983b, p. 5). Death equals pain and pleasure and is close to the Lacanian jouissance. The tearing apart of the female body is left in the blank of the text as though ungraspable by the Logos. The reader is only provided with the beginnings of a disguised and abjectified sexual intercourse.

The disguised connotation of rape and the negation of the body are also apparent in Misery (1987) whose plot revolves around two characters. Victim of a car accident, a successful writer, Paul Sheldon, is taken by his number one fan and a former nurse, Annie Wilkes, to her house but the necessary recovery care turns into a torture to have him resuscitate her favorite character, Misery. Annie is the very epitome of a paradox; she progressively annihilates Paul's body and identity but she is also perceived as his muse despite her body described as deformed and her deviant personality. Ungendered, dehumanised, "there was a feeling about her of clots and roadblocks rather than welcoming orifices or even open spaces, areas of hiatus [...] as if she might not have any blood vessels or even internal organs” (King, 1987, p. 11), she is assimilated to a female dragon, to a castrating figure.

Both Annie's and Paul's bodies are submitted to a fragmentation process. After Paul discovers she is a long time murderer, Annie amputates his left foot with an axe. The action, set in slow motion, emphasises the movements of her hands or her spreading of her legs; depicted in her utmost sensuality, Annie holds the axe endowed itself with a phallic power. The amputation of his foot is a clear penetration and castration of the male body: "the axe came whistling down and buried itself in Paul Sheldon's left leg just above the ankle” (King, 1987, p. 139). The bodily fragmentation rimes with the omnipresence of a disguised and morbid sexuality. The act of castration accentuated by the disruption of the syntax, “can't suture [...] No time. Tourniquet's no good. No central pressure point. Got to (rinse) cauterize” (King, 1987, p. 139), echoes the fragmented way the character's body is presented. The hypermonstration of the suffering and fragmentation of the body coincide with a pouring out of blood. The shattering of the male body transforms the latter into a gaping wound: the text monstrates the torn apart flesh, the comparison of his leg with a piece of meat, assimilating this barbarous act to a rape.

The corporeal fragmentation is magnified by the in-betweenness characterising the description process. King lays the emphasis on the bloody aspect of the castrative act, the movement of the axe on the bone, Paul's wriggling toes and his bleeding stump; yet, the cauterization of his stump with the blowtorch is hardly mentioned: "Paul screamed as fire splashed over the raw bleeding stump. Smoke drifted up. [...] His leg lays in a line of flames with his severed foot wavering beyond it” (King, 1987, p. 139). The extreme pain leads Paul to wish to fall into oblivion, to vanish like the letters e, $n$, and $t$ fall apart on the typewriter she bought for him. Although he completes the words manually, the signifiers are clearly deconstructed on the page, echoing the fragmentation of his own identity.

The final battle between the torturer and its victim expresses the female-male domination relationship and the male's willingness to stifle and destroy the genitalia. After months of detention and different attempts at escaping, Paul desperately burns a fake version of a finished manuscript and throws the typewriter at Annie's back. Her fall on the floor with the burning paper below her chest, her wriggling and moaning when Paul is on top of her are accompanied with the use of the term "rape” (King, 1987, p. 195). The burning paper soaked with 
champagne stuffed into Annie's mouth stresses the invasion of her body with the presence of a liquid reminiscent of the seminal liquid:

Paul let himself fall on top of her. This pushed her down on to the hard typewriter. She screamed in pain again and tried to push him off. She rolled over on to her back. He grabbed some paper, which was lying in a pool of champagne, and squashed it into a ball. 'Get off me!' she shouted, and her mouth opened wide. Paul pushed the ball of paper into her mouth. "Here’s your book, Annie,” he gasped, and he grabbed some more paper. She struggled under him [...] he kept his position on top of her and fiercely punched more paper into her mouth ... and more and more, until the first balls of paper were deep in her throat, making it impossible for her to breathe. (King, 1987, p. 195)

The sexualisation of the act is stressed by the terms "on top of, push down, hard, scream, ball, opened wide, push into, deep in”. The lexicon of rape is indissociable with the focus set on the characters' hands, mouth, and throat; the accumulation of paper and the insistence on the act of stuffing place the reader in a state of scopic drive, makes him a viewer of the destruction of the monstrosized feminine body.

Therefore, the theme of sexuality, either seen in a redemptive or deviant/destructive manner, is in link with the monstration of the fragmented body, whether in an entirely disclosed way or in a disguised manner. If King does not shy away from sexuality, its taboos, more precisely rape and incest, are equally ubiquitous in his texts as well as the revealing of their physical and psychological aftermaths.

\section{Sexuality and Its Taboos}

Rape and incest exert a shattering force upon the characters' bodies and sanity. Rape is presented in a direct manner in The Stand (1978), Bag of Bones (1998), or Under the Dome (2009). In The Stand, a struggle rages between the forces of good and evil after a biological experiment causes the spread of a virus and the downfall of the whole USA. A woman, Nadine Cross, has been chosen for years to be the devil's bride and willingly awaits to sacrifice her virginity to the Dark Man, Randall Flagg. The narrative underlines her sexual craving: "her body ached in a slow and unrelieved cycle of desire. It felt almost like menstrual cramps" (King, 1978, p. 917). Nevertheless, the long-awaited intercourse turns the supposed love and desire into disgust: "his smooth, lineless hand slipped around her... and then closed over them tight, like handcuffs” (King, 1978, p. 1212); "he revolts me, she thought" (King, 1978, p. 1213). Although she rejects the filthy union at the last moment, "it's much too late to say no" (King, 1978, p. 1214). The moments preceding the rape lay the stress on her scared face, her terror at seeing the phallic organ whose lack of description only reinforces the abject and inhuman aspect of the intercourse:

She saw what he had for her and began to scream. [...] Nadine pealed forth scream after scream and tried to crawl away and he grabbed her and then she was holding her legs shut with all her strength, and when one of those blank hands inserted itself between them they parted like water and she thought: I will look up... I will look up at the moon... I will feel nothing and it will be over... It will be over... I will feel nothing... And when the dead coldness of him slipped into her the shriek ripped up and out of her, bolted free, and she struggled, and the struggle was useless. He battered into her, invader, destroyer, and the cold blood gushed down her thighs and then he was in her, all the way up to her womb, and the moon was in her eyes, cold and silver fire, and when he came it was like molten iron, molten pig iron, molten brass, and she came herself, came in screaming, incredible pleasure, came in terror, in horror, passing through the pig-iron and brass gates into the desert land of insanity... (King, 1978, p. 1214)

The dark man, assimilated to a rigid rod, is indifferent to her pain or pleasure. What is brought to the fore is the violation of Nadine's vagina signalled by the gushing blood; her feeling of pleasurable terror is 
reminiscent of Burke's experience of the sublime ${ }^{1}$ though, in her case, it results in the loss of her sanity underpinned by the repetition of the idea of negation: "feel nothing... be over".

The seemingly endlessness of the rape, only meant for procreation, is highlighted by the length of the sentences or the ternary repetition of the preposition "again": "he went again ....and again...and again" (King, 1978, p. 1214). Rape obliterates Nadine's body in the text itself: at the minute of the penetration, she stops thinking and becomes one with the suspension points used eight times during the abject act. She becomes a blank slate, "a big doll with a seed hidden carefully in its belly” (King, 1978, p. 217) denied of any feelings. Nadine's suicide will constitute the sole way out from the realm of blankness insanity has confined her into.

The impossibility of coping with the trauma of rape is also visible in Under the Dome in which the town of Chester's Mill becomes separated from the rest of the world by an impenetrable dome. The invisible, unnameable barrier triggers a destruction of the common law and rational behaviours. A totalitarian regime is set up and delinquents are chosen to be law officers. Three of them (Mel Searles, Frankie DeLesseps, and Carter Thibodeau), under the influence of alcohol and in search for drugs, gang rape the single mother, Sammy Bushey, while her child is asleep. They are encouraged in their atrocious act by a female cop, Georgia Roux, whose humiliating words_- “do her, do that bitch” (King, 2009, p. 490)—have a haunting force for Sammy. The rape itself is expressed with three verbs/phrasal verb: "do, push into, ride” (King, 2009, p. 234). An invasion of her body, "he pushed into her. Carter was next” (King, 2009, p. 234), rape immediately makes this body a blank; between the acts of penetration, Sammy’s body is no longer mentioned.

The violence lays in the lack of description of the act and in its aftermath: the trauma of the suffering body and the shattering of Sammy's mental balance. The immediate aftermath of rape is body oblivion with a twelve hour sleep, immediate thoughts of suicide and killing her baby by mixing drugs with his food. Only forty pages later does the narrative come back on the destruction of her vagina due to her dryness:

DeLesseps hadn’t been so bad, but Carter had hurt her top and made her bleed down below... Worse had followed, when Mel Searles dropped his pants, he was sporting a tool like the ones she's sometimes seen in porno movies. [...] Searles had gone at her hard [...] she had felt it puddling under her warm and sticky. During Mel's endless ride, it came to her that he might actually killed her. (King, 2009, p. 291)

The flow of blood running from her body is depicted as endless: "she stuffs the crotch with toilet paper", then with "a folded dish-wiper. [...] She was still bleeding... And it had gone on all night. The bed was soaked" (King, 2009, p. 293). Despite having already been involved in drug-fuelled threesomes or in one-night stands, she feels "depressed, sad, hurt, dirty, degraded” (King, 2009, p. 291). Unable to cope with the traumatic act and with the perception of her body as something other, her vagina becomes a terra incognita, "the Land Down Under” (King, 2009, p. 294), she eventually shoots one of the male cops as well as the female cop in her face and neck. The annihilation of the organs responsible for her physical and mental imbalance (the phallus and Georgia's voice) marks the beginning of oblivion finalised with her suicide; the silencing of her mind is the only way to "peace" (King, 2009, p. 525).

\footnotetext{
${ }^{1}$ In A Philosophical Enquiry into the Origins of Our Ideas of the Sublime and the Beautiful, Edmund Burke talks in the following terms of the sublime: "whatever is fitted in any sort to excite the ideas of pain and danger, that is to say, whatever is in any sort terrible, or is conversant about terrible objects, or operates in a manner analogous to terror, is a source of the sublime; that is, it is productive of the strongest emotion which the mind is capable of feeling”. Unruly, terrifying and never fully graspable, the sublime is associated with the feeling of delight, a pleasurable fear attainable when this fear is experienced from a safe enough distance. Nadine experiences feelings of terror and horror facing a force larger than human cognitive capacity can comprehend. Her fall into insanity may be accounted by the immediacy of her contact with this otherness.
} 
The themes of bodily negation and anger permeate Bag of Bones. The house where the protagonist Mike Noonan finds refuge after his wife's death and the whole woods surrounding it are haunted by a black blues singer, Sara Tidwell, raped and murdered in the summer of 1901. Her revenge consists in cursing and killing all the descendants of her torturers who also murdered her son. Her rape once more projects the silencing and the death of the female body. The villain, Jared Devore, whose name already indicates his desire to devour the fearless black woman, along with six other friends punish her for behaving like a white girl and debase her at the mere state of a nigger: "her and her big teeth and her big tits and her snotty looks. She thought she was something special, but we taught her different” (King, 1998, p. 605). Rape is from the white male viewpoint a means "to keep the community pure" (King, 1998, p. 608), to stifle the black female overwhelming hypnotizing sensuality.

The violence of the rape lays in the accumulation of facts and in the length of the act. One of the rapists forces her into oral sex but the scene is left undescribed. The act of rape is equalled to the erasure of her thoughts. The action, not detailed at great length, stresses the use of her body as an object:

They take her top and bottom, back and front, two and three at a time. [...] And it doesn't end. There's come down her throat, come running down the crack of her ass, the young one has bitten the blood right out of her left breast, and it doesn't end. They are young, and by the time the last one has finished, the first one [...] is ready again. (King, 1998, p. 614)

The term "vagina" is not used; she is reduced to her throat, bottom, and breast. The negation of her body reduced to holes or orifices is underlined. A gaping wound, her body is voidified. Her death by strangling is mentioned in a unique sentence: "behind him Sara is choking her last" (King, 1998, p. 621) while death is concomitant with pleasure for the impotent Jared who only has an erection when he orders his friends to kill Sara's son: "he slips it to her, what she's wanted all along, what all her kind want. He slips it in and sinks it deep. He continues giving orders even as he rapes her" (King, 1998, p. 619). The abundant imagery of penetration and violation of the female's vaginal orifice confirms the likening of the female body to a mere hole instrumentalized for the male pleasure.

The perception of the objectified, holified female body, at the same time filled and negated by the phallic organ or by male abject desires, shares common ground with the depiction of incestuous acts in Gerald's Game (1992c) and Dolores Claiborne (1992b). The protagonist of Gerald's Game, Jessie Burlingame, is, at the beginning of the narrative, handcuffed to a bed by her villain husband; refusing to play his sex game, she gives him a violent kick near his intimate parts, causing a heart attack and a quasi immediate death. King declines the themes of imprisonment and of the fallen state of the body. From sex games to being hunted by her own childhood memories, Jessie has to find a way to release herself from the handcuffs so as not to be the victim of a serial killer. Entrapped in the bedroom, in the handcuffs but also in her own mind with numerous voices confronting one another, her memory forces her to re-experience the loss of her innocence that occurred when she was ten years old. From this immersion into those memories will the clue reveal itself as to how to escape her nightmarish situation.

The weakening of her own body (the excruciating hunger, cramps, muscle spasms, absence of sensations, advanced dehydration) is viewed in unison with the revisiting of the incestuous act-qualified as a "heap of rotting meat” (King, 1992c, p. 135)—and kept secret to preserve the fake unity of the family: 
The secret of that day had never been completely sunk in her subconscious [...] it had been buried in a shallow grave, at best. There had been some selective amnesia, but of a completely voluntary sort. If she wanted to remember what had happened on the day the sun had gone out, she thought she probably could. (King, 1992c, p. 105)

Taking place during an eclipse, the incestuous act was preceded by precursory signs, like the close connection repeatedly stressed out between Jessie and the father figure. Sexual undertones permeate the text: the moment of the eclipse is equated to a date when Jessie suggests she cooks dinner and he suggests she puts on a tight and short dress and lipstick. The focus is set on the awakening of her sensuality:

The girl looking back at her from the mirror didn’t seem like a girl at all, but a teenager. It wasn't the way the sundress accentuated the tiny swellings that wouldn't really be breasts for another year or two, and it wasn't the lipstick, and it wasn't her hair, held up in a clumsy but oddly fetching chignon; it was all of these things together, a sum greater than its parts because of ... what? She didn't know. Something in the way the upsweep of her hair accented the shape of her cheekbones, perhaps. Or the bare curve of her neck, so much sexier than either the mosquito-bumps on her chest or her hipless tomboy’s body. (King, 1992c, pp. 200-201)

The complete awareness of her changing body-the insistence on her breast, hair and neck-echoes her grasped cognition of the power she can possess on male desire. The sexualisation of her body is accompanied with the emphasis on her father's nudity and extreme virility. The drop of sweat on his belly troubles her and his kiss on her hand makes her shiver. The vision Jessie has of them being cast away from the house by her mother like Hansel and Gretel sleeping together at night enhances her fascination for the drop of sweat on his belly, which is itself analeptic of the drops of sperm on her panties.

During the incestuous act perceived through Jessie's innocent eyes, she hears the change in her father's voice while his hand pulls her dress up: "something was pressing against her bottom. It wasn't painful but it was insistent” (King, 1992c, pp. 183-184). If Jessie’s body parts are mentioned-breasts, legs, thighs, pubis - the father is eventually reduced to his hand and "something pink" or "something hard" (King, 1992c, p. 195). Her imprisonment on her father's lap—she is retained by his hand on her pubis, she is forbidden to turn and look at him—-parallels the fact that she has remained prisoner of the day of the eclipse her whole life.

The hand on her thigh now moved between her legs, slid up until it was stopped by her crotch, and cupped her firmly there. He shouldn't be doing that, she thought. It was the wrong place for his hand. Unless, He's goosing you, a voice inside suddenly spoke up. (King, 1992c, p. 191)

Though not penetrated, her vagina is a space covered up with a hand and the filling up of this space brings the father to the climax of pleasure at the very moment of completion of the eclipse. The incestuous act is marked with ambivalence, fear and pleasure: "he arched suddenly beneath her, sending her smoothly upward. The movement was both terrifying and strangely pleasurable” (King, 1992c, p. 191). Likewise, the sperm is an intriguing substance whose flat odor and thick texture makes her throw out; this reaction equals a rejection of the abject experience that cannot be translated into words.

Jessie's struggle for survival triggers the return of the repressed. Reliving the incestuous act is necessary to escape the prison of her past; she has to accept she is not guilty of having encouraged her father's behaviour:

If you still think your dear old Daddy was a parfit gentle knight who spent most of his time shielding you from the fire-breathing mommydragon, you better think again. [...] He planned it, Jessie. Don’t you understand? It wasn't just some spur-of-the-moment thing, a sex-starved father copping a quick feel; he planned it. (King, 1992c, p. 227) 
The re-experiencing of her symbolic deflowering leads her to perceive the necessity of using her blood — the blood she has not poured as a child—as a lubricant to escape from her handcuffs:

Now Jessie understood the purpose of that old, hurtful memory...The answer had nothing to do with the old Adam or with the faint mineral smell of the wet spot on her old cotton underpants. It had everything to do with half a dozen panes of glass carefully cut from the crumbling putty of an old shed window. She had lost the jar of Nivea cream, but there was still at least one other source of lubrication left to her, wasn't there? ... There was blood. Until it clotted, blood was almost as slippery as oil. (King, 1992c, p. 238)

The release from the handcuffs can be likened to a symbolic death with the focus laid on the lacerations of her body, her confrontation with the serial killer and her final fainting in the car. The text insists on her torn apart flesh and her flowing blood:

The sharp edge severed the blue bundles of vein lying closest to the surface of her skin, and the blood began flowing out faster. It did not come in the pulsing jets she had expected but in a fast, steady flow, like water from a tap which has been spun almost all the way open. Then something bigger parted and the stream became a freshet. It coursed across the shelf and spilled down her forearm. [...] The back of her hand looked like a turkey drumstick from which the crispy outer skin had been removed. The steady downward pressure she was exerting had yanked the wound across her inner wrist even wider, creating a blood-caked chasm. Jessie wondered if she might not yank her hand right off in this final effort to free herself. (King, 1992c, p. 250)

The ludicrous comparisons give a carnivalesque hue to this auto sacrifice which hammers out the fragmented perception of her body in parallel with her fragmented identity. This initiatory trial also allows a recognition of her body as her own possession; it is a symbolic death necessary for a symbolic rebirth. The incestuous act and the scene of release from the handcuffs share a hyper consciousness and monstration of the body.

The issue of incest permeating Dolores Claiborne is also in connection with the theme of entrapment but the female body is viewed as searching for concealment, oblivion. In this narrative, the familial home turns into a gothicified locus of imprisonment and silencing for the daughter, Serena, pursued by her father's pressing urges. The whole narrative is Dolores's testimony who analeptically expresses the dichotomy between the coming of Selena's femininity, her outwardness and close bond with the maternal figure and the walls she confines herself into after she is hunted by her father, Joe: "there was a coldness that hadn't been there before" (King, 1992b, p. 78). The verb “court” (p. 78) used to qualify Joe’s behaviour towards his daughter actually echoes the fatherly attitude in Gerald's Game.

Selena becomes distant with her parents, loses appetite and makes herself look ugly. She covers her body with layers of cloth to hide her femininity. She becomes an absence so Joe forgets her presence and his attraction to her. The deconstruction of the familial bond and her identity go along with a deconstruction of the linguistic idiom. King inserts an absence of words between Selena and her parents: "She pretty much quit talking to everybody" (King, 1992b, p. 85). Following Derrida's vision of silence as being a marker of negation participating in the postmodern theory of deconstruction, King has his character become a blank slate, an empty body.

Selena no longer uses complete sentences; besides, the abject acts Joe makes her perform are not clearly depicted in the text: "he'd done just about everything a man can do to a woman short of fucking her... and frightened her into doing any number of things to him, as well” (King, 1992b, p. 101). The text echoes with the suspension points the act of secrecy the father asks from his daughter. 
The blanks filled in by Serena for Dolores lead to the only possible outcome: the murder of the father figure entirely embraced by the readers and viewed as necessary to regain the unity and sanity of the family nucleus. The pit chosen as a place for the father's death is emblematic of the postmodern in-betweeness present in King's novels: the presence of the water at the bottom of the pit makes it a feminine space but its elongated erected shape approaches it to the phallus. The mother figure epitomizes the vagina dentata devouring the villain patriarch before he devours her and her offspring. The pit ruptures spaces and mirrors the deconstructed perception of the female body.

Therefore, the body in link with sexuality either talks in terms of negation (when connected with rape or when the link with sexuality is presented in a disguised manner) or in terms of ambivalence (in a healing-destructive paradigm or in the case of incest). The oscillation between hypermonstration and absence plays a role in the otherisation of the body when the latter is monstrosized, blurring the frontier between male and female, human and animal.

\section{The Otherized Body}

The Tommynockers (1987) stresses the hypermonstration of the abjectified female body representing the collapsed link between signifier and signified. The spaceship discovered in the woods of Haven by Bobbi Anderson vampirically feeds from the inhabitants' minds and energies in order to regenerate itself. The "evolution" claimed to be followed by Bobbi and the other citizens goes towards a state of uniformisation, the metamorphosis into Tommynockers. Their hybridity is at the image of the Tommynockers who are at the same time perceived as monsters, intergalactic travelers, an advanced race, modifiers, and shifters. Bobby's transformation goes beyond a state of desexualisation: it takes the hero, James Gardener, and the readers at the core of the abject, in a place where meaning collapses; the female body stands as a thing both recognizable and rejected because of its surpassing the reach of our cognition.

She loses her teeth, her hair; her skin becomes translucid, jellylike. Blood, as one of the auxiliaries of the abject for Kristeva, ${ }^{2}$ is otherized and replaced by a green fluid: "there was fluid circulating in there but it looked green”. Her breasts merge into "one single nippleless outcropping of flesh” (King, 1987, p. 710). The "grotesque thatch of tentacles like sea-grass waver[ing] from her vagina" (King, 1987, p. 711) epitomizes the theme of the vagina dentata and the mingling of the human and sea element. Her parodic scenes of seduction and the grotesque medusean qualification of the female sexual organ shatter the unicity of the body, not only ungendered but hybridicized. Bobbi's sister, Anne, is silenced by the in-between quality of Bobbi's body; this silence, conveyed by the suspension points "Bobbi...” (King, 1987, p. 711), highlights the rupture of signifiers and signified. The process of deconstruction is at the level of the body and language; King stages an obscene parody of the corporeal essence. The body is other due to its semblance with the known and places the onlooker as a voyeuristic observer of an unacceptable scene when the tentacles capture Anne in "a movement that was like an obscene parody of copulation” (King, 1987, p. 711).

The process of becoming and the theme of the vagina dentata establish a bridge with the novel, Rose Madder (1995). Rose Daniels tries to escape from the assaults of her villain husband, Norman, after 14 years of suffering. The shredded remains of the novel she is reading as Norman comes home echoes the state of her own identity crushed to nothingness. An oil painting untitled "Rose Madder" ushers her into the realm of the

\footnotetext{
2 The abject stems from three elements: food, bodily waste, or the feminine. King does not make use of menstrual blood but he modifies the fluid of life.
} 
one-eyed bull, Erinyes, hiding at the heart of a labyrinth on a hill, and the world of Rose Madder, Rose's evil doppelganger. King masculinizes the myth of the Erinyes, feminizes and monstrosizes the mythical Theseus. ${ }^{3}$ The arachnean form associated with Rose Madder reminds the reader of the form taken by the extraterrestrial god-like monster in King’s It. Nobody can look at Rose Madder in her eyes for fear of turning insane:

It was a spider's face, twisted with hunger and crazy intelligence. The mouth that opened gave upon a repellent blackness afloat with silk tendrils to which a hundred bugs and beetles stuck fast, some dead and some dying. Its eyes were great bleeding eggs of rose madder red that pulsed in their sockets like living mud [...] he screamed, he screamed, he screamed; it was oblivion he was screaming for, oblivion and an end to knowing and seeing." "There were claws at the ends of the black not-arms, filthy with bristles. The claws settled on his wrists, his legs, the swollen appendage which still throbbed in his crotch. One wriggled amorously into his mouth; the bristles scraped against his teeth and the insides of his cheeks. It grasped his tongue, tore it out, flapped it triumphantly before his one staring, glaring eye. (King, 1995, pp. 423-424)

The combining of the arachnean shape, the fragmented perception of the creature, the vaginal aspect of its mouth and the draining quality of its claws make it utterly abject. Norman's reaction confirms the otherized female body as being a looking-glass opened onto the Real. ${ }^{4}$ Confronted with its ungraspability, Norman can only utter screams and wish for emptiness before his voice and body disappear from the pages.

Both narratives refer to the female body as an annihilating force but also as an object of fascination and repulsion. It is not only a vehicle of captation but it also hammers out the idea of an inescapable return to the entrapping womb. The shed juxtaposed to Bobbi's house conceals, in old galvanized steel shower cabinets, two persons and a dog kept alive in a gluey emerald green liquid. The intra-uterine quality of the shed finds an echo with Rose Madder's world inside the painting. ${ }^{5}$ If the otherized female body allies fascination and repulsion, the otherization of the male figure is not so much linked to specific organs as to the ebbing away of the body from the pages of the text.

The novel Thinner (1984) stages the fate of Billy Halleck, a successful obese lawyer, cursed by Taduz Lemke, a centenary gypsy, to lose weight until he dies after driving over the gypsy's daughter. The beacon of irony sheds light on Billy's fate as the latter is sealed by the very element he adores, food. His imposing corpulence, the gargantuesque breakfasts he swallows up highlight his ogresque nature: "she put breakfast in front of him: a steaming mound of scrambled eggs, an English muffin with raisins, five strips of crisp country style bacon. Good eats” (King, 1984, p. 7).

Once Billy's skinniness changes him into a freak, food turns from an element of pleasure to an element of repulsion. He looks at the food on his hand with the same revulsion he will look at himself in the mirror when realizing his freakishness:

Every rib stood out clearly. [...] His cheekbones bulged. His sternum was a congested knot, his belly a hollow, his pelvis a gruesome hinged wishbone; [...] Above the waist, he really was turning into a carny freak-the Human Skelton. (King, 1995, p. 160)

\footnotetext{
3 They are in mythology the Furies, female personifications of vengeance. The husband steps into the painting wearing the mask of a bull with horns. He takes on the figure of the mythical Minotaur but with one eye and is killed in the centre of the labyrinth by Rose madder.

4 Magritte's painting The Looking Glass (1963) comes to mind. The dark crack represented through the frame of a window pane offers an insight into the impossible Real.

${ }^{5}$ On her way to the temple of the bull, Rosie is drenched by the rain, walks on drenched stones, smells semen and blood, walks across a stream and wet grass.
} 
His body is vampirically eaten away by the curse; the body eats away its own calories, devours its own fat and flesh until only a living skeleton remains. Thinner epitomizes the remnants of the body after it has evaporated all of the digested food and after the body itself has been digested by the gypsy curse. The ultimate vanishing of the body corresponds to a blank in the narrative when otherness permeates the text. This disappearance of the character's body along with the body of the text finds and echoes in the short story " $\mathrm{N}$ " (King, 2008).

The reduction of the protagonist to a single letter already foreshadows the progressive emptying of his identity and body. A circle of eight rocks he discovered at the end of a path in Ackerman's Field opens the door on an evil dimension. $\mathrm{N}$ is convinced that the fate of humanity lays in his hands and it is only by counting the stones and counting everything in life that the monstrous creatures hiding behind the eighth stone will not invade the human world. Counting is a symbolic act to solidify the reality of the world and keep the eight stone from shimmering out of existence: "that sense of thinness swept over me again, as if the world was fragile at this particular place, and one person would be enough to cause an unimaginable cataclysm” (King, 2008, p. 195). The faces of beasts and monsters he sees drive him to apparent lunacy and suicide.

This other space, suffused with the uncanny, ${ }^{6}$ also gives an insight into the Real causing the fissures in the sanity and eventually the complete silencing of his body in the text. The suspension points, the numerous repetitions echo the split in his sanity: "I felt myself divide ..." "That split in my mind was tearing me apart. Is tearing me apart” (King, 2008, p. 209). Sentences become incomplete or composed of a single word: "But!” (King, 2008, p. 219). Signifiers are rendered as deformed and ungraspable as the name of the creature he sees behind the 8th stone, Cthun: "symbolic, solstitch, solstit, dyed, bastyard” (King, 2008, p. 223) or "loox, thru, relief, fare” (King, 2008, pp. 223-224). Cthun, a meaningless juxtaposition of letters, is only an echo of the vanishing of punctuations, the repetitions, the shorter and shorter sentences the text is studded with. The fragmented body and the fragmentation of language reveal the unrepresentability of the body invaded by the supernatural other.

\section{The Corporeal Fragmentation}

The body invaded with otherness thus becomes a figure of negation. The Shining (1977) is suffused with the idea of the non-self vehicled through the monstration of the father's deformed, possessed, monstrosized body: "it was Jack and yet not Jack" (King, 1977, p. 441); "there was nothing of real Jack in that howling, maundering, petulant voice” (King, 1977, p. 456). Privative suffixes or terms pertaining to the lexical field of emptiness inscribe the notion of loss in the text itself. Reduced to a ripped face and body, depicted only through body parts, the father figure is the epitome of a paradox: he leaves the predicate of the living human being while continuing living. He is close to the Lacanian concept of "Lamella". The father's body is an uncanny excess of life, an indestructible life-substance that persists beyond the death of the original body, the libido as an organ without a body. He is an organism existing for the sake of the drive energy of the Overlook Hotel. ${ }^{7}$

The traumatized, unformed bodies in Desperation (1996) oxymoronically embody a nothingness caused

\footnotetext{
${ }^{6}$ The distorted reality perceived through this space shows the cracks in our realm of significance: "the leaves are black instead of green and the branches are twisted... they seem to make letters and the letters seem to spell...you know... its name” (King, 2008, p. 207).

7 Although the Lamella is a life that does not need an organ to exist in Lacan's theory, the father's thingified body appears as a vehicle of the destructive-based libido of the hotel, leading to the likening of the father to a pre-subject with a deconstructed face. He becomes a symbol of life beyond all the finite forms.
} 
by the evil spirit, Ka, taking possession and bringing about the decay of the characters' bodies. The policeman, Collie Entragian, lets out blood and a raw tissue whose rotted smell indicates his decaying body: "he was a kind of blood-gorgon, a creature who appeared to be disintegrating before their very eyes” (King, 1996, p. 223). The incantation "tak ah lah" (King, 1996, p. 95) expresses this non-existence; it designates the "tongue of the unformed" (King, 1996, p. 413) that only animals can understand and obey, "or maybe nothing at all, just a name, nonsense syllable—but a dangerous nothing” (King, 1996, p. 536). The body is invaded by the ungraspable, reduced to oozing orifices, transformed into a looking-glass, allowing, like Magritte’s painting, to glance into the unknown. The fragmented and vanishing body turns into an Id-machine since it goes beyond the grasp of our cognition and any fantasy can be projected upon it.

Two short stories in Skeleton Crew (1985) underpin the fragmentation of the body and hint at its non-knowledge. “The Raft” introduces the readers to four college students (Rachel, Dake, Laverne, and Randy) in Pennsylvania who decide to celebrate the end of summer by swimming in a lake up to an isolated raft in its middle. A dark patch, first believed to be an oil-slick, preys on them revealing itself to be a vampirish creature that produces hypnotizing colors on the surface of the water. Rachel's body is the first to be totally absorbed by the patch. When Deke decides to swim up to the shore, his foot is grabbed by the creature and his body is shown to be consumed through the crack between two boards. The disappearing body is first viewed in a fragmented manner before being unified with the Thing and offers a total immersion into the Real. The crack between the boards equals King's representation of the opening in Magritte's looking glass.

The black stuff surged up again, sucking, eating. Deke wailed. [...] Blood burst from the pores of Deke's calf and shin; his kneecap had taken on a purple, bulging look as it tried to absorb the tremendous pressure being put on it as the black thing hauled Deke's leg down through the narrow crack inch by inch. [...] Deke died just as his thigh began to disappear into the narrow crack between the boards. [...] The rest of his right leg disappeared, his left leg stretching out further and further until Deke looked like a one-legged ballet dancer doing an impossible split. [...] Deke's head appeared to be sitting on the boards. His eyes were still open. His tongue was still sticking out. (King, 1985, pp. 305-308)

The repetition of the verb "disappear", the references to gaps serve the metamorphosis of the body into a silent signifier. The unbearable sight of the body turned into a vehicle of horror places Randy between a scopic drive and a refusal to look. The transformation of the body into an "inhuman” (King, 1985, p. 300) thing inscribes the character and the reader into a state of captation: "Randy looked away for a long time, trying not to hear the wet sounds" (King, 1985, p. 308). "Randy looked away again, out across the lake [...] (Minutes passed... he looked anyway”) (King, 1985, p. 309). The ultimate absence of description for Randy's death only leaves for the reader the incomprehensible black spot, a symbol of devouring orality, and the lake.

The disembodiment of the body on the page echoing the disembodying of the text itself is exemplified in "Survivor Type”. Following a shipwreck, a surgeon, Richard Pine, is the only survivor on a desert island with at its sole disposal a large amount of heroin but no food. Depicting a case of auto-cannibalism, King monstrates a body that becomes an absence on the page. The character eats his left foot, his right leg at the knee, his left leg at the knee, his thighs, his earlobes and finally one of his hands. The loss of landmarks is visible in the entry dates, “February 7; (later); February 8; february 9; February 11 (?); Feb 17 (?); Feb?; February 23 (?); February; Fe; Febba; Fe/ 40?”, the incorrect grammar, the absence of subjects in the sentences, the absence of punctuations, or the segmentification of the sentences. ${ }^{8}$ The vanishing of his body- “there's nothing left for

8 “This. Is where it. Happened.” (King, 1985, p. 449). 
[my hands] to cut off” (King, 1985, p. 450)—accompanies the foodification of his body, the shrinking of the words on the page or the rupture of his grasp on reality. King only presents the outcome of the surgical operations_-“'ve amputated my left foot and have bandaged it with my pants” (King, 1985, p. 446); "Took off my right leg at the knee, but lost a lot of blood” (King, 1985, p. 448)—while "The Raft” insists on the process of disembodiment itself.

Therefore, the body is either made Other through an ambivalent or a deviant sexuality, a blurring of gender, a process of desexualisation, invasion, fragmentation, and negation. The oscillation between hypermonstration and absence only highlights the vision of the body as appearing as a figure of unknowability, a spot of indeterminacy.

\section{The Non-knowledge of the Body}

In "The Body” (Different Seasons, King, 1992a), a child's dead body becomes the vehicle of four boys' darkest fantasies precisely because of this ungraspability. The narrator, Gordon Lachance, analeptically tells his initiatory journey with his friends, Chris Chambers, Vern Tessio, and Teddy Duchamp to see the body of teenager, Ray Brower, made Other by the trauma of death. The following quotes reveal the hypnotic fascination exerted by the slow discovery of the unknown:

We were in Harlow now, in the woods. Somewhere up ahead was a dead kid, probably mangled and covered with flies. Maggots, too, by this time. Nobody wanted to get too close to him with the night coming on. (King, 1992a, p. 510)

The fascination of the thing drew on us and kept us walking faster than we had any business doing, in that heat. We were all crazy to see that kid's body—I can't put it any more simply or honestly than that. (King, 1992a, p. 524)

At the bottom of this washout was a marshy, mucky tangle of undergrowth that smelled bad. And sticking out of a wild clockspring of blackberry brambles was a single pale white hand. [...] It would have been better to see the whole body, all at once, but instead there was only that limp outstretched hand, horribly white, the fingers limply splayed, like the hand of a drowned boy. (King, 1992a, pp. 540-541)

It is not simply a fascination for the abject body but the text is also pervaded with the theme of unknowability, engendering a frantic urge to witness the corporeal negation and the representation of non existence. The boys' quest is to comprehend the secrets a dead body can expose, the need to see the "Something" left after the non-recognition of the body. King stages a monstration of unknowability, an excess of unsayability that is an echo of Slavoj Zizek's analysis of the Thing as an intrusion of the Real into the Symbolic.

The non-knowledge of the body is equally rendered vibrant by the endings of the narratives that offer no closure but rather a constant loop into a state of indecision. In Thinner, the wandering Billy Halleck eventually finds a way to pass away his curse; yet, he decides, when he sees his daughter has eaten a part of the strawberry pie bearing the curse, to condemn his body once more to a descent into inferno. The ending of the novel announcing the total self-erasure of the body is an absolute emptiness the readers have to complete by themselves. The aim achieved is the same with the ultimate cutting off of the surgeon's hand in "Survivor Type”, which marks the end of the diary. The ending of Pet Sematary (1983b) immerses the reader into the crack of non-existence. After the father, Louis Creed, uses the malevolent power of the Micmac burying ground to resuscitate his son Gage who ends up killing his mother, Louis decides nonetheless to bury her and awaits for his wife's return. The ultimate sentence of the novel—“a cold hand fell on Louis's shoulder. Rachel's voice 
was grating, full of dirt. 'Darling,' it said” (King, 1983b, p. 465)—combines the fragmentation of the body and that of the text. The reader is left with a stain of the Real: a hand and a unique word which, italicized, indicates his out-of-this-world quality. The hand itself is left undescribed but it plunges the narrative into a complete void, which is, just like the hand, a trace of the traumatic otherness.

The accumulated ruptures, blanks, suspensions points, repetitions, disjointed sentences, and deconstructed signifiers establish the meaningful indeterminacy of the body. Its unresolved ungraspability would be endowed with the same impact as Georges Bataille's notion of inner experience: a necessary experience of transgression equalling a constant state of in-betweeness and entailing a permanent act of doubting and confusion. The faithfulness of King's constant readers shows the fascination for the fissured, even sacrificed bodies, for a constant oscillating state between life and death, morality and immorality, the sacred and the profane, presence and absence, hypermonstration and void. The body cannot be shaped "into a full-fledged object of cognition, and consequently, an object of nomination” (Nagornaya, 2014, p. 2). King makes it an anchorage of rupture, of an impossible reassertion of the symbolic.

\section{Conclusion}

At the image of King's work, this article unveiled a kaleidoscopic view of the body in the American writer's narratives. He clearly does not shy away from the theme of sexuality and its taboos (rape and incest). In the diverse representations of the sexual act either seen crudely or in a disguised and deviant manner, the female body is hypermonstrated or silenced. King also stages otherized bodies, whether they are feminine and in that case ungendered, abjectified, or masculine and in that case submitted to physical and psychological fragmentation verging on their vanishing in the blanks of the text. The thingification of the body echoes a deconstruction and even voidification of the very signifiers. The omnipresence of fragmentation, of the voidified body, of absence is significant of the stain of the real in King's texts. The impossibility of reaching closure renders the body properly postmodern. The instability of the body—a signifier refers to other signifiers: a car becomes a mistress, a werewolf is a lover, a clown is an extraterrestrial monster-the instability of the body of the text itself, mingled with the impossibility of reaching closure (there hardly is a reassertion of the symbolic order at the end of his narratives), account for the spots of indeterminacy running in the veins of his narratives. The Kingian bodies endlessly remain the vehicles of our darkest fantasies.

\section{References}

Bataille, G. (2001). L'expérience intérieure (The inner experience). Paris: Gallimard.

Bataille, G. (2010). Discussion sur le péché (Discussion on sin). Paris: Lignes.

Burke, E. (1757). A philosophical enquiry into the origins of our ideas of the sublime and the beautiful. Retrieved from http://www.gutenberg.org/files/15043/15043-h/15043-h.htm

Derrida, J. (1967). Of grammatology. Paris: les Editions de Minuit.

Freud, S. (2003). The uncanny. (D. McLintock, Trans.). New York: Penguin.

King, S. (1977). The shining. New York: Doubleday.

King, S. (1978). Night shift. New York: Doubleday.

King, S. (1978). The stand. New York: Doubleday.

King, S. (1979). The dead zone. New York: Viking Press.

King, S. (1983a). Christine. New York: Viking Press.

King, S. (1983b). Pet Sematary. New York: Doubleday.

King, S. (1983c). The cycle of the werewolf. New York: New American Library.

King, S. (1984). Thinner. New York: Signet. 
King, S. (1985). Skeleton crew. New York : Putnam's Sons.

King, S. (1987). Misery. New York: Viking Press.

King, S. (1987). The Tommyknockers. New York: Putnam.

King, S. (1992a). Different seasons. New York: Viking Press.

King, S. (1992b). Dolores Claiborne. New York: Viking.

King, S. (1992c). Gerald's game. New York: Viking.

King, S. (1995). Rose madder. New York: Viking.

King, S. (1996). Desperation. New York: Viking.

King, S. (1998). Bag of bones. New York: Scribner.

King, S. (2008). Just after sunset. New York: Scribner.

King, S. (2009). Under the dome. New York: Scribner.

King, S. (2014). Mr. Mercedes. New York: Scribner.

Kristeva, J. (1982). Powers of horror : An essay on abjection. New York: Columbia University Press.

Lacan, J. (1977). Ecrits: A selection. New York: Norton.

Lacan, J. (1978). Four fundamental concepts of psychoanalysis. New York: Norton.

Magritte, R. (1963). The looking glass.

Nagornaya, A. (2004). Stephen King's body worlds: Language conventions and creativity in depicting the inner body. Athens Journal of Humanities and Arts, 1(1), 55-68.

Zizek, S. (1999). The Thing from Inner Space. Mainview, September 1999. Retrieved from http://www.lacan.com/zizekthing.htm 